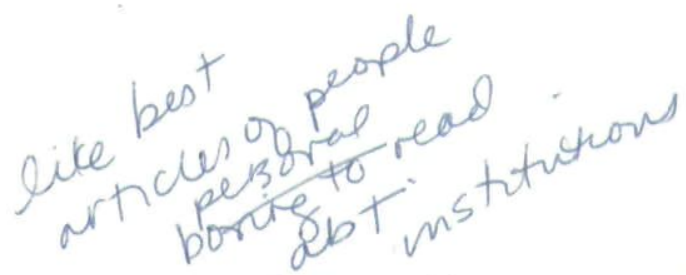

\title{
Cooperative Extension and Rural Iowa: Agricultural Adjustment in the $1950 \mathrm{~s}$
}

\section{DOROTHY SCHWIEDER}

THE DECADE OF THE 1950s was a pivotal time for rural interests in Iowa, a time of trial both for Iowa farm families and for the Iowa State College Cooperative Extension Service that served them. By successfully transmitting technological and scientific information to Iowa's farm population, Extension officials helped to bring about major increases in agricultural production. At the same time, the state's farm families were facing severe economic problems, including ever increasing surpluses, low farm prices, and increased farm costs. An examination of Extension's efforts to deal with these apparently unsolvable problems in the 1950s reveals much not only about Extension itself, but also about the society that Extension was created to serve.

Extension offered four major responses to the social and economic changes of the fifties. In response to broad concerns about rural society, Extension implemented the Home and Family Development Program to provide an integrated approach to farm living. In response to economic difficulties in particular, Extension promoted public policy education to help Iowans become better informed about economic issues and world affairs. In addition to these two programmatic innovations, Extension made two fundamental internal adjustments. As hard times continued, Extension officials began to consider ways to help bring farm production into balance with demand, thus calling into question the agency's long-standing commit-

THE ANNALS OF IOWA 51 (Fall 1992). (C) The State Historical Society of Iowa, 1992. This article is adapted from a chapter in the forthcoming book, Seventy-Five Years of Service: Cooperative Extension in Iowa, to be published by Iowa State University Press in 1993. 
ment to maximizing agricultural production. Finally, in the midst of this difficult decade, Extension was forced to separate from the Iowa Farm Bureau Federation, ending a partnership that had existed for forty-two years. ${ }^{1}$

BY MID-CENTURY, the Iowa Cooperative Extension Service had established a highly successful program. During the previous twenty years, Extension had successfully met the challenges of two extreme emergencies - a depression and a world war. By 1951, the central staff included more than one hundred people trained in the various phases of Extension work. County Extension staffs included more than two hundred workers: every county had an agricultural director (formerly known as county agent); approximately 70 counties had home economists; and 33 had youth assistants who worked primarily with 4 - $\mathrm{H}$ clubs. ${ }^{2}$ At the same time, because the prosperity of the war years had continued into the early fifties, Iowa farm families had money to spend on farm machinery and modern household equipment. Many farm families were remodeling kitchens, landscaping farm yards, and even building new homes.

By 1953, however, Iowa's farm income began to drop, signaling the beginning of difficult times. A slump in food exports took place even earlier in 1950, but the Korean Conflict provided a "temporary solution." As one economic report put it, "by 1953, 'the farm problem' began to take shape againsurpluses, lower farm prices, lower farm incomes, higher farm costs." At the same time, there was increasing evidence that "agriculture was out of adjustment with the rest of the national economy; resources elsewhere in the economy were earning increasing returns while returns to resources in agriculture were decreasing. Though the national economy as a whole was growing, agriculture was not sharing fully in the fruits of a progressive economy." ${ }^{3}$

1. This article focuses on four major responses, but Cooperative Extension carried on a myriad of additional programs, many of which had been in place before the 1950 s. For example, $4-\mathrm{H}$, though not discussed here, was a highly successful program in the 1950 s.

2. Iowa State Department of Agriculture, Iowa Yearbook of Agriculture, 1951, 419.

3. Basebook for Agricultural Adjustment in Iowa, part 1, "Agriculture in the Mid-Fifties," Special Report No. 20 (Ames, 1957), 2. 
The economic downturn of the early fifties took place during a time of great agricultural expansion. Historian Wayne D. Rasmussen has characterized the period of the forties and fifties as the "second American agricultural revolution." As a result of research done by the U.S. Department of Agriculture, the state experiment stations, and industry - and delivered to rural people by Extension personnel-farmers had adopted a "package of practices" that involved "looking at every part of the farm operation and doing what was possible to improve each part." As Rasmussen describes it, "These experiments [combined] the application of the most productive levels of nitrogen fertilizer, the use of hybrid seed, adherence to suitable conservation practices, use of appropriate mechanical power, and the effective control of pests and disease" to greatly raise production levels. ${ }^{4}$

Faced with these seemingly contradictory conditions, the central issue for Extension was concern about the poor economic conditions for farm families. Yet the ever increasing pace of scientific and technological research meant that Extension experts constantly had to update their own staff as well as Iowa farmers on the newest research findings. Extension officials also promoted good management practices that would enable farm families to achieve their economic goals. Longtime Iowa Extension staff member Ed Graff wrote in his memoirs that as early as 1952, Extension personnel were expressing concern about the role of the Extension Service. ${ }^{5}$

BEFORE EXTENSION OFFICIALS had much time to respond to the economic downturn, however, they faced a major organizational change. In 1954, U.S. Secretary of Agriculture Ezra Taft Benson ordered that "extension could no longer accept funds from private organizations or submit to the direction of a private organization in the conduct of its responsibilities." In effect, this order required that Extension and the

4. Wayne D. Rasmussen, Taking the University to the People: Seventy-Five Years of Cooperative Extension (Ames, 1989), 120.

5. J. B. Claar, "Farm and Home Development," in The Cooperative Extension Service, ed. H. C. Sanders (Englewood Cliffs, NJ, 1966), 284; Ed Graff, Memoirs, Ed Graff Papers, Parks Library, Iowa State University, 51. 
Iowa Farm Bureau Federation sever their longtime relationship. The next year the Iowa General Assembly responded to Benson's directive by repealing the Farm Aid Association Law passed in 1913, which had called for the creation of county farm aid associations to act as sponsoring agencies for Extension. Over time, those associations became known as farm bureaus. ${ }^{6}$ If the sponsoring associations (the county farm bureaus) had remained just that-sponsoring associationslater conflict would have been avoided. The Iowa county farm bureaus, however, soon organized into the Iowa Farm Bureau Federation, which, in turn, helped organize the American Farm Bureau Federation in 1920. That organization then developed its own staff and programs. In short, the Farm Bureau took on a life of its own, in addition to serving as a sponsoring agency for Extension.

The relationship between Extension and the Farm Bureau was a continuing source of controversy and misunderstanding. From 1913 into the 1950s many Iowans criticized the close tie between county farm bureaus and county Extension staffs. Farmers who did not belong to Farm Bureau often charged that Extension personnel gave special consideration to those who did. Officials of the Farmers Union labeled the relationship "the unholy alliance," asserting that their members hesitated to request assistance from Extension because of the organization's tie to Farm Bureau. Grange officials occasionally echoed the charge. In fact, membership in Farm Bureau was not a prerequisite to participation in any Extension program, but many Iowans were under that impression, a misconception that lasted into the fifties. According to a history of the Iowa Farm Bureau Federation, if the membership workers, who sometimes included county agents, were questioned as to whether families had to belong to Farm Bureau to take part in Extension programs, particularly $4-\mathrm{H}$, the workers would obviously say no. If

6. D. B. Groves and Kenneth Thatcher, The First Fifty: History of Farm Bureau in Iowa (Lake Mills, 1968), 199, 202-4; Iowa State Department of Agriculture, Iowa Book of Agriculture, 1954-1955 (hereafter cited as IBA with date), 341-43. The Farm Aid Bill was replaced by the County Agricultural Extension Law, which provided for the creation of county councils to assist with the administration of Extension in every county. County councils would then carry out the work previously done by the Farm Bureau county boards. 
no one asked, however, workers would not be unduly concerned if a farmer assumed that he had to join Farm Bureau for his children to participate in $4-\mathrm{H}^{7}$

It is easy to see why Iowans were confused about the relationship between the two organizations. Although county agents formally represented only the Extension Service, they were actually jointly employed by Iowa State College (the parent organization for Extension) and the Farm Bureau (the sponsoring farm aid society), represented by a Farm Bureau county board. In their daily interactions with farm people-passing along scientific and technical information, helping to solve production problems, and cooperating with dozens of local organizations - county agents (later agricultural directors) represented Iowa State College. On the other hand, agents often sold Farm Bureau memberships to county residents, thus closely identifying themselves with Farm Bureau in the minds of farm people. Agents had a vested interest in Farm Bureau memberships, because the 1913 law required that at least two hundred memberships in the farm aid association be sold before Extension qualified for county tax money. When a county needed to hire a new agent, a district Extension official brought the candidates (previously interviewed by state Extension officials in Ames) to be interviewed by the Farm Bureau county board. Once the board and Extension officials agreed upon a particular candidate, the county board helped negotiate the new agent's salary. Each county's annual Extension program was also strongly influenced by the Farm Bureau county board. ${ }^{8}$

In many counties, Extension agents and county Farm Bureau representatives shared the same office and the same secretary. From the 1920s on, Farm Bureau had established var-

7. Groves and Thatcher, The First Fifty, 200. Although many criticized the relationship between Farm Bureau and Extension, there were also many strong supporters of the relationship. One of these was Ralph K. Bliss, who served as director of Extension for more than thirty years. See Ralph K. Bliss, History of Cooperative Agriculture and Home Economics Extension in Iowa-The First Fifty Years (Ames, 1960), 138-40.

8. Marvin Anderson (ISU Dean of Agriculture and Home Economics and director of Extension, 1966-1974), telephone interview, Ames, Iowa, 28 February 1992; Bliss, History, 66. 
ious business interests, such as the sale of farm supplies and insurance. Sometimes farm products were sold out of the shared Extension-Farm Bureau office. ${ }^{9}$ The shared facilities and blurred responsibilities not only created confusion, but also led to criticism of the close relationship between the two organizations.

An additional source of criticism concerning the Farm Bureau-Extension tie stemmed from the Farm Bureau's political activity. Since the 1920s, Farm Bureau had engaged in political activity (such as opposing daylight saving time). By the forties the organization included the position of research director and lobbyist, and by the fifties Farm Bureau strongly opposed federal price support and adjustment programs, which it viewed as the dominant political issue of the period. Sometimes the Farm Bureau took part in political campaigns. It was most active in the governor's campaign in 1948 when members and leaders campaigned for William S. Beardsley, whom they viewed as a supporter of their organization; they thought the incumbent, Robert D. Blue, opposed them. Of course, many interest groups engaged in political activities, but Farm Bureau's formal tie to a public agency cast that activity in a different light. ${ }^{10}$

Some Extension and Farm Bureau officials greeted the "divorce" with trepidation, but the separation offered advantages to each group. Both organizations could then move in new directions. Farm Bureau could further develop business and political activities without fear of compromising Extension's image as an independent, unbiased public agency. At the same time, Extension officials no longer had to consult with Farm Bureau officials regarding staff, budgets, programs, and

9. Anderson, interview.

10. Groves and Thatcher, The First Fifty, 96, 115, 212. The National Farmers Union was often cast as the major critic, not only of the relationship between Farm Bureau and Extension, but sometimes, such as in the thirties, of Extension itself. On the political spectrum, Farm Bureau and the Farmers Union occupied opposite ends of the spectrum: Farm Bureau represented the more prosperous farmers; the Farmers Union championed the small farmer and supported government farm support programs. See David Edgar Lindstrom, American Farmers' and Rural Organizations (Champaign, IL: Garrard Press, 1948), 204-19. 
policies. Even though the two organizations shared many basic views on agriculture and farm living, there were always some policy disagreements and differences in basic organizational goals. The separation in 1955 left Extension free to develop innovative programs based solely on its own perceptions of the needs of its constituents.

EXTENSION had continually developed new programs in response to its constituents' economic and social needs, but in the 1950 s several conditions merged to produce a more comprehensive program, one that departed from the organization's traditional approach. In 1954 Congress appropriated money for state Extension Services to carry out the Farm and Home Development Program (FHDP). The program's main focus was longrange social and economic planning by farm families, involving the entire family. As one Extension director explained it, "A concept running through [FHDP] objectives is that the farm family is really the important unit in the farm business. How the plans for the cropping and livestock program affect the family living and the satisfactions they get out of farming [are] a major concern." The director further explained that farm decisions should be made by families, and that the farm wife as well as the farm husband should understand the family business. ${ }^{11}$

A number of conditions had led to the formation of the Farm and Home Development Program. Extension's belief that constituents needed to "understand management principles and to apply them in their individual situations" was one factor. Extension personnel also realized that specialists' work, established in all states by the late forties, had its limitations. In a report issued by the U.S. Department of Agriculture and the Association of Land-Grant Colleges and Universities, officials observed that the farmer "wanted to profit from what he hears [from the specialists]. But the more specialists there are to serve him, the more complicated becomes the job of fitting together their varied recommendations into a workable whole suited to his soil, his financial situation, his preferences and abilities, his

11. Annual Narrative Report of County Extension Agents (hereafter cited as ANR), Hardin County, 1955, vol. 6, p. 2. 
family needs, his market outlets, and all other significant factors bearing upon the most practical course to follow." The report continued, "This committee would point out that farm life itself is not lived in segments or projects. It is lived as a whole. The operator faces a multitude of problems of which production is one, marketing another, conservation of soil resources another, and so on. The end objective of solving all these problems is a better life for the farm family and the insurance of an adequate supply of agricultural products for the general public." 12

When Iowa began to implement a farm and home program in 1952, the state's Extension personnel, like their counterparts elsewhere, thought in terms of projects for its clients. Each county staff member expected to promote projects that would serve one part of the farm family. Home economists, for example, offered farm women the option of working with projects such as home management, nutrition, or clothing construction. Although each area of work-agriculture, home economics, and youth-clearly had become more complex since the twenties and thirties, county personnel for the most part still worked in the same general areas as before. In the early fifties, however, Iowa Extension began to provide a new integrative approach to the farm family through the FHDP. In the process, the Extension Service was moving from projects to programs that involved broader issues affecting several or possibly all family members.

Iowa Extension initially designed FHDP primarily for young families, often those just getting started in farming. Extension officials selected two counties, Hardin and Wayne, to initiate the program, which they then expanded the next year to include nearly eight hundred farm families from thirty-four counties. Extension specialists at Iowa State College in Ames prepared new program materials, designing them to deal with problems related to all aspects of farm life, not just agricultural

12. Claar, "Farm and Home Development," 284; the quote from the USDA/ ALGCU report is taken from Edmund DeS. Brunner and E. Hsin Pao Yang, Rural America and the Extension Service: A History and Critique of the Cooperative Agricultural and Home Economics Extension Service (New York, 1949), 52-54. Brunner served on the committee that issued the report. 
issues. Extension Director Floyd Andre pointed out in his 19541955 annual report that the new materials dealt with matters such as "family goals and values; farming opportunities and how to make effective use of them; how to choose among various cropping systems and livestock systems; what is needed in a satisfactory farm rental arrangement; ... and how to use budgets and farm and home records to solve management problems." Iowa's program was apparently modeled on earlier programs, such as one established in Illinois, but it differed somewhat from those in other states in its emphasis on teaching economic principles and in restricting the program to younger families. ${ }^{13}$

The 1955 Hardin County annual report indicates that the principle of "the farm as a family affair" was to be interpreted broadly and applied to every aspect of farm life. The Extension staff first helped the family appraise their general situation and background and set family goals. In the words of Director Andre, the program helped families "see more clearly what they want to accomplish in farming, homemaking and family living." Then, after asking the family to consider what changes in their farming operation or family living patterns they might be willing to make, Extension staff assisted them in organizing "the human, physical, financial and community resources they have or can call upon" to accomplish those changes. ${ }^{14}$

Throughout the program, staff emphasized that Extension personnel provided participating families with "ideas, information and counsel," but the family made and implemented its own decisions. Extension staff stressed the importance of good record keeping in helping families make informed decisions. They also encouraged participating farm couples to take a

13. IBA, 1952-1953, 421; IBA, 1954-1955, 344-46. Whereas most of the Iowa participants were young families, in Minnesota in 1961 only 198 of 1,799 participants were new farmers. See Rasmussen, Taking the University to the People, 124. In 1954-1955 Congress appropriated special funds for the program which allowed Extension to employ additional home economists, assistant county directors, and county youth assistants in counties where the program had not yet been started. See Charles Donhowe, "Certain Economic Principles in Farm and Home Development" (M.S. thesis, Iowa State University, 1959), 52, 57.

14. ANR, Hardin County, 1955, vol. 6, p. 2; IBA, 1954-1955, 344-45; and Donhowe, "Certain Economic Principles," 59. 
greater role in community affairs, apparently in the hope that the program would produce future community leaders. ${ }^{15}$

Extension personnel quickly perceived the need to understand differences among farm families. The Hardin County agricultural director insisted that the program must be flexible because individuals needed different degrees of assistance. "Some couples may require individual counciling [sic] over a two or three year period while others will grasp the ideas presented and progress without individual attention." Some farm couples were obviously more predisposed than others to accept new ideas. Social considerations were also important. The director observed that "many wives are reluctant to come to the meetings because of feelings of inferiority and the inability to meet people. These things have been noted during individual home visits." The agent added, "It is also important not to let the program get a reputation of being for down-and-outers, or couples will be reluctant to take part." As a later study also pointed out, "The stigma of an educational program to assist low income farmers has purposely been avoided in Iowa."16

By 1957, more than half of Iowa's counties had instigated the FHDP with 1,455 young families participating, an increase of 607 families over 1956. The overall rate of participation was high, but the number participating varied widely among counties. Wapello County had one hundred families enrolled, while the adjacent counties of Monroe and Jefferson had only six and none respectively. The level of commitment of the agricultural director and the home economist to the program undoubtedly had a good deal to do with the number of couples involved within a given county. As with so many Extension programs, if county staff were interested, the overall rate of participation was high. ${ }^{17}$

Farm families often made far-reaching decisions as a result of their participation in the FHDP. In 1957 Director Andre

15. IBA, 1956-1957, 303; and Donhowe, "Certain Economic Principles," 56. 16. ANR, Hardin County, 1955, vol. 6, p. 11; Donhowe, "Certain Economic Principles," 59.

17. IBA, 1956-1957, 303; Donhowe, "Certain Economic Principles," 56. According to Donhowe, 54, 1,878 Iowa families participated in 1957-1958. By comparison, Minnesota had 1,209; Wisconsin, 2,054; Illinois, 2,377; Missouri, 6,328; Nebraska, 503; and South Dakota, 444. 
reported that 144 participating families obtained larger farming units, 38 through the purchase of additional land and 105 by renting more land; 100 families decided to enlarge their farming operations; 390 families made major reorganizations within their farming enterprises that contributed to increased income or improved efficiency; and 258 farmers intensified existing enterprises. At the same time, 44 families "left the farm for other employment." ${ }^{18}$ In effect, the message seemed to be: If the family could not expand their operation or increase their profits, then perhaps it was best to consider another line of work.

By decade's end, the FHDP was still in effect but had undergone change. In 1959 the Hardin County agricultural director devoted attention to the program but cast it primarily in terms of farm business analysis. In that year fifteen farm families were taking part in the county program. In 1958 Director Andre reported that the long-range concerns of farm people had changed little and that they were still primarily concerned with their families. "Extension must be geared to help the family," he insisted, even as he focused less on FHDP than in previous reports. Andre observed that many participating familiesabout two thousand altogether- "fall within the low income bracket and nearly a third have had no previous experience of participating in Extension programs." While Andre thought it was too early for a complete assessment of the program, he did observe that the annual income of participating farm families in 1958 showed an increase of 44 percent over the previous year, while that of all Iowa farmers increased only 24 percent. ${ }^{19}$ In light of Extension's early concern that Farm and Home Development not be for "down-and-outers," the increased involvement of low income families might have influenced Extension's views toward the program.

Elsie Van Wert, who worked with the FHDP when she served as an Extension home economist in Hancock and Winnebago counties during the fifties, recalled the "human development" aspect of the program which she believed brought husbands and wives together to discuss mutual problems. Van Wert explained that in certain situations, "Women

18. IBA, 1956-1957, 304.

19. ANR, Hardin County, 1959, vol. 7, p. 23; IBA, 1958-1959, 288-89. 
could see why the men had to have the tractors. [And why] they couldn't have the piano. ... And it brought them together and they realized what they needed to do, what their priorities had to be in order to get them where they wanted to be. [Before] they weren't looking ahead far enough, planning ahead." After participating in the program, Van Wert added, "farm women said 'You know, we didn't realize all this was necessary.' And the men would say, 'why I didn't realize my wife felt like this.' It was human development."20

Van Wert's comments underscore a significant shift in Extension policy. Before 1950, Extension had followed a sexsegregated approach in regard to clients: county agents served male farmers while home economists worked with farm women. Farm men and women did attend social and educational programs together, particularly those developed by rural sociologists, but the main work of county staff resulted in different projects for each sex. In the FHDP, Extension personnel viewed the family as an integrated unit; agricultural directors, home economists, and specialists such as agricultural economists all worked with both husbands and wives. With the assistance of staff, farm couples made joint decisions regarding many farm practices. As Van Wert pointed out, joint decision making led to better understanding by each spouse of the needs and concerns of the other. ${ }^{21}$

The FHDP represented greater change for farm women than for farm men. Although the term family farm had been used for some time to describe farming operations in the Midwest, in reality male farmers typically made major farm decisions. Most farm women earned money through the sale of eggs, cream, and butter, but decisions to make major nondomestic purchases were viewed as male decisions. To them, investments in farm buildings, additional livestock, and new machinery usually seemed more sensible than household improvements. The FHDP encouraged participating families to

20. Elsie Van Wert, interview with author, Garner, Iowa, 11 February 1988. 21. For a discussion of the gender gap, see Jane B. Knowles, "The United States Cooperative Extension Service: The Origin of the Gender Gap" (Paper presented at American Farm Women in Historical Perspective Conference, New Mexico State University, Las Cruces, 2-4 February 1984). 
discuss decisions mutually and give equal weight to all family needs. It is doubtful that such mutuality took place in every case, but at least the interests and desires of farm women were being considered, not only concerning domestic matters, but in regard to the entire farming operation. For perhaps the first time, Extension officials had established programs that provided for mutual decisions and elevated domestic work and concerns to the same level as agricultural concerns. ${ }^{22}$

A SECOND EXTENSION PROGRAM of major significance during the fifties also sought to provide information that would enable Extension's constituents to make informed decisions about public policy. In the 1950s Extension launched a program of public policy education. Although public policy programs did not actually take place until after 1950, Extension agricultural economists as early as the 1920 s were telling farmers that events off the farm significantly affected their welfare. At that time, however, officials viewed involvement in social or public policy as perhaps not legitimate or safe for their organization. ${ }^{23}$ Extension officials feared that their agency would be viewed as an advocate for certain issues rather than as an impartial educator. After all, Extension's major commitment was to greater productivity and prosperity for the state's farm population, not to particular social and economic policies.

In 1944, however, federal Extension officials began discussions with state Extension staff about the need for public policy work. The push for these programs in the 1940s is understandable given the national and international events of the period. It was clear by 1944 that the United States would play a major international role in the postwar era, far different from the position the country had taken after World War I. With the emergence of internationalism, Extension officials at all levels sensed the need to help the nation's farm population understand political and economic issues more thoroughly.

22. For an in-depth study of Iowa farm women, see Deborah Fink, Open Country Iowa: Rural Women, Tradition and Change (Albany, NY, 1986).

23. Leon Eugene Thompson, "Cooperative Extension and Public Affairs Education" (M.S. thesis, Iowa State University, 1954), 121-22. 
The planning of public policy education programsplanning that began in 1944-was a response to these as well as local needs. Moreover, public policy education reflected Extension's most basic mandate: Extension was (and continues to be) an educational agency. It had always tried to inform Iowans about a multitude of issues. The educational process was often extremely specialized, as when county agents provided information on the treatment of hog cholera. But in the post-World War II era, Extension leaders believed farm people needed a broad understanding of "federal agricultural programs, tariffs, foreign trade, and economic issues." 24

Also in 1944, just as federal Extension officials were integrating public policy education into their postwar planning, the Association of Land-Grant Colleges and Universities issued a report, Postwar Agricultural Policy, which singled out three issues that federal Extension officials believed should be emphasized in most state postwar public policy educational programs: foreign trade, fiscal and credit policies, and agricultural adjustment. Described as "an articulation of land grant college thinking," the report helped legitimate Extension's public policy work. Further, the report defined the policy role of land grant colleges not as determining policy but as presenting citizens with information that would enable them to recommend policies. According to one study, the report guided state Extension personnel by clarifying "the value position of Extension" on public policy and by identifying some "major issues on which extension specialists in public affairs could develop educational programs." 25

Another influential report, The Joint Committee Report on Extension Programs, Policies, and Goals, followed in 1948. Known as the Kepner Report, it stated that state Extension Services should initiate public affairs education programs. The report recognized that some issues would be "less tangible and more controversial" but it argued that Extension must accept its educational responsibility. According to one authority, this report was "considered a landmark by many workers in extension public affairs education," and it responded to reservations

24. Ibid., 41, 49-50.

25. Ibid., 41, 49-50. 
that had blocked state Extension Services from earlier moving into this field of study. ${ }^{26}$

The federal Extension Service under M. L. Wilson helped move state Extension personnel along the road toward public affairs education. In 1949 Director Wilson brought together personnel from eighteen state Extension Services that had experience with public affairs work. The conference identified some guiding principles for conducting such education. It also secured a commitment from the Farm Foundation to support the first public policy education conferences that would soon follow. The Farm Foundation, an organization concerned with improving the economic, social, educational, cultural, and intellectual welfare of farm people, continued to be involved with public policy education for many years. ${ }^{27}$

In the same year, federal Extension officials started to prepare state Extension staff to deal with public policy issues. A survey taken in 1949 indicated that such work had already begun in Iowa, Montana, Vermont, California, Michigan, Tennessee, and Wisconsin. At a conference held for Extension workers of the north central states in 1950, the keynote speaker observed that in the early days of Extension, farmers "had been trained to think in terms of personal interests rather than public interests." Presently, he observed, agriculture was just one phase of the total economy, and farmers needed to understand broader issues and the relationship between agriculture and the rest of society. ${ }^{28}$

Iowa's Cooperative Extension first began specific action on public affairs education in January 1946, when Extension agricultural economists Wallace Ogg and Carl Malone held two informational meetings in northwest Iowa on fiscal and monetary policy for full employment. Enthusiastic reactions to the two meetings, attended mainly by farm leaders, prompted Ogg and Malone to request a statewide series of similar meetings. In 1948

26. Ibid., 55-56.

27. Ibid., 74. The Farm Foundation had been established in 1933 from funds left by former International Harvester president Alexander Legg and by former Illinois governor Frank Lowden. See ibid., 59.

28. Ibid., 62; Discussing Public Policy: A Report of the North Central States Conference (Madison, WI, 1950), foreword and p. 1. 
Extension created a new position of Extension Economist in Public Affairs, and hired Wallace Ogg for the post. For the next several years, Ogg and Malone worked together conducting public policy meetings organized around the theme, "Peace and World Progress." The two men also covered subtopics such as "Understanding Europe," "Understanding Asia," "Understanding Russia," and "American Foreign Policy." As part of their responsibilities, they trained field staff to work with the program. ${ }^{29}$

Ogg and Malone presented twelve half-hour programsfour on farm policy, four on fiscal and monetary policy for full employment, and four on foreign policy. In the winter of 19531954, the two men began to develop a public affairs program combining television presentations with discussions in private homes. This approach was possible because WOI Television was located in Ames. Extension officials urged county agricultural directors to organize groups of farm men and women who would meet in private homes to watch the television presentation and then discuss the issues. The staff distributed discussion materials to participants serving as discussion leaders at each gathering. Extension estimated that from twenty-five hundred to five thousand people took part in the programs. By 1955, in response to the state's increasing agricultural difficulties, Ogg and Malone concentrated their public policy presentations on farm policy. As the Iowa programs got under way, Ogg and Malone's innovative work was recognized not only in the state, but nationally as well. An Extension official later described their work as "being on the cutting edge" of public policy work nationally. ${ }^{30}$

A year later, county Extension staff began conducting public policy meetings on their own. While other states apparently held the view that only specialists were qualified to do the work, Ogg and Malone trained county staff to make their own presentations. In Franklin County, Extension personnel devel-

29. Thompson, "Cooperative Extension," 93. The Farm Foundation sponsored annual training conferences for Extension workers, including agricultural directors, home economists, and other staff members. These annual training conferences continued at least into the early 1960s. See ibid., 68, 173.

30. Ibid., 93-94; Ronald Powers, interview with author, Ames, Iowa, 28 November 1988. 
oped a team presentation on farm policy that received state and national attention. County officials made the presentation to fifteen hundred Franklin County residents as well as over four area television stations. Eventually the U.S. Secretary of Agriculture invited the team to appear before the National Agricultural Advisory Committee. The U.S. Department of Agriculture produced a motion picture of the presentation, making it available to other states, and citing the Franklin County program as an example of what could be done by a county Extension staff in that field of study. ${ }^{31}$

The development of public policy education in the 1940s and 1950 s certainly represented one way that Cooperative Extension carried out its educational mandate, but it also helped break down the last vestiges of isolation by bringing farm people into the mainstream of political and economic awareness. Like farm populations elsewhere, Iowa's farm families were socially isolated throughout the first three decades of the twentieth century. Often a provincial view dominated families' thinking; the life style of one generation was deemed sufficient for the next. While some farm children attended high school in nearby towns, the majority did not, at least through the 1920s. In the 1940s and 1950s, however, farm families began to live more like their urban counterparts mainly because of better transportation (through improved country roads) and electrical conveniences in farm homes. Public policy education was another means of bringing the world to the doorstep of the Iowa farm family.

\section{IN SPITE OF EXTENSION'S SUCCESSFUL PROGRAMS} designed to share information with farm families, agricultural conditions had not improved in Iowa by late 1955. In response, Extension began an "intensive self-analysis," a thorough review of the current agricultural situation and of its own programs.

31. Thompson, "Cooperative Extension," 95; Edna Ogg, wife of Wallace Ogg, telephone conversation with author, Ames, Iowa, 15 March 1989. In the late fifties, Extension sponsored two public policy programs, "Our Changing Agriculture" and "Challenge to Iowa." Participation in both programs greatly exceeded Extension's expectations. Officials had hoped that 50 counties would participate; instead 96 out of Iowa's 99 counties participated "to some degree." See An Extension Service in Transition, 1956-1960 (Ames, [1960]), 11. 
The "package of practices" promoted by Extension to increase the efficiency of agriculture had been effective: farmers were purchasing larger and more efficient farm machinery; plant and animal scientists were breeding "more productive crop varieties" and improved herds of livestock; farmers were using more chemicals, including insecticides, fungicides, and herbicides as well as fertilizer; and more farmers were specializing in one or two main crops. ${ }^{32}$ For Iowa farmers, these changes had resulted in greater and greater production of corn and soybeans as well as livestock.

Extension officials had always urged Iowa farmers to adopt new technological and scientific findings and to move toward more efficient operations, but it should also be noted that they usually had a willing clientele. As Gilbert Fite has written, farmers themselves "wanted to increase their efficiency and production to improve their incomes. Farm families wanted to enjoy the same standards of living as people in nonfarm employment. They wanted to modernize their homes, to buy household appliances, to educate their children, and to take vacations like town and city folks." 33

Given the complexity of the problems facing Iowa's agricultural sector, the Extension staff quickly concluded that approaches taken before 1956 were not always successful and that the organization needed to search for new ones. At the same time, Extension made it clear that it would not abandon its "fundamental obligation" to provide technical services to agriculture. As part of what officials later called a "transition period" between 1956 and 1960, Extension took several steps to help Iowans better understand the economic difficulties they faced. It sponsored a seminar for the College of Agriculture staff to study "Adjustment of Agriculture to Economic Change," and held conferences for county Extension councils to inform them of current economic conditions. The same year, Extension officials created the Center for Agricultural and Economic Adjustment at Iowa State College, described as an agency "to provide information to help farm families achieve incomes on a

32. Gilbert C. Fite, American Farmers: The New Minority (Bloomington, IN, 1981), 110-13.

33. Ibid., 114. 
par with those received in other industries and occupations." Extension also published the papers presented at the seminar which provided the basis for much later discussion and analysis. Extension's major response, however, was to emphasize public policy education to better inform Iowans of existing economic and social problems. ${ }^{34}$

While new approaches such as public policy education and FHDP achieved some success, one hard fact remained: economic conditions had not improved in rural Iowa. The annual Plan of Work for 1957, prepared by Extension's central staff, noted that "farm income is decidedly unsatisfactory and is falling further and further behind that of the rest of the economy." The report also noted that more and more farm men and women were holding off-farm jobs to supplement their farm income. For many families, such a work arrangement was becoming permanent. ${ }^{35}$

The 1957 Plan of Work, reflecting the growing agricultural surpluses, cited the need to bring "total farm output into balance with total demand. An unprecedented slowing down of farm output growth must take place if demand is to catch up with output." In turn, the report noted, an even further slowdown in production must take place if "excess farm stocks are to be liquidated." The second basic approach was "the adjustment that will permit each farm family to have an adequate economic base for their farming operation. The direction needed is to spread the labor and capital over the larger acreage of land; thus, larger farms and more extensive farming methods rather than more intensive ones." In effect, Extension officials were stating explicitly what staff members had been implying for some time: Iowa might have too many farmers and perhaps some should leave the farm permanently. ${ }^{36}$

34. The state legislature appropriated one hundred thousand dollars to establish the center, known today as the Center for Agriculture and Rural Development, or CARD. See "An Extension Service in Transition," 6.

35. Plan of Work: Cooperative Extension Work in Agriculture and Home Economics, State of Iowa, 1957 (Ames, 1957), A-2.

36. Ibid., 4. As FHDP was implemented during the fifties and carried over into the early sixties, leaving the farm was one option discussed with couples who were viewed as not having the financial capabilities for expanding their agricultural operations or the resources to continue in farming. 
In elaborating on these approaches, the report stressed two basic points. First, young people needed to understand the current "limited nature of good opportunities in farming" and to understand that this situation would likely persist for some time. Extension officials believed that this understanding would cause some young people to decide against farming as a career, thus further decreasing the farm population. Second, established farm families needed to "reappraise their income potential in farming." This would mean that some families might conclude that they could do better economically in other occupations. If Extension could encourage some less productive individuals to move into another line of work, there would be opportunities for the more efficient ones to enlarge their acreages. This then would enable the more productive farmers to make a greater profit and would relieve them of some pressure to farm as intensively as before. ${ }^{37}$

Not all decisions to leave the farm turned out happily. Wallace Ogg relates in his memoirs, "I distinctly remember the meeting of a series on Agricultural Adjustment to Farm Size and Equipment. A janitor in the [Iowa State College] Memorial Union came up to me after the meeting. With intense anger in his voice and his facial expression, he said, 'I am an example of this agricultural adjustment. I used to be a farmer and enjoyed it. Now I am a janitor here in the Union.'"38

By the end of the decade, Iowa indeed had fewer farmers than in 1950. Director Andre reported in 1960 that Iowa's farm population had dropped a little more than 5 percent between 1949 and 1954 and an additional 9 percent between 1954 and 1960. The Extension director also pointed out, however, that agricultural surpluses remained. Contrary to the thinking of some agricultural economists, fewer farmers were producing an ever increasing supply of food. ${ }^{39}$

37. Ibid., 4; Basebook, part 2, "Prospects for the Years Ahead," 32.

38. Wallace E. Ogg, "My Career as a Public Affairs Specialist," 1989, excerpt from the unpublished memoirs of Wallace E. Ogg, "In Retrospect," which describes twenty-five years of Ogg's professional work, Parks Library, ISU.

39. IBA, 1960, 284 . 
BY THE END OF THE FIFTIES, Iowa's Extension Service had undergone almost a decade of frustration because of the state's agricultural troubles. Agricultural adjustment had proven to be elusive and exceedingly difficult to attain. In response to these trying times, Extension had developed new programs and new approaches. Through public policy education, Extension worked to help Iowa farm men and women understand public policies and international issues. In spite of earlier fears, the Extension Service did not turn into an advocacy group. Extension also changed in its philosophy of service and its delivery system. During the 1920s and 1930s, Extension personnel had concerned themselves primarily with greater agricultural production, spending considerable time helping farmers solve specific problems. The county agent or the home demonstration agent often prescribed a solution for a problem, based on information obtained from Extension specialists, the state experiment station, or the agents' own considerable experience. Through the forties, individual projects dominated the work of all county staff and subject matter specialists. But during the following decade, Extension emphasized programs that would encompass the entire family, rather than individual groups. The FHDP provides an excellent example of this transition in philosophy and approach which was, as a former agricultural director put it, a change from practices to principles.

While the fifties would not bring economic prosperity to Iowa farm families, the sixties would. With the return of "good times down on the farm," some of the programs devised during times of stress would be forgotten. The need to question past policies seemed less immediate once farmers were again making money. The FHDP would continue into the $1960 \mathrm{~s}$, but within a few years would fade away. Prosperous times, at least in the sixties, did not seem to demand that farm families continue with an integrated, long-term planning approach. Residue of the program likely remained in the countryside where some farm men and women undoubtedly continued joint decision making. On the other hand, public policy education would continue to be an important part of Extension work. The programs had proven their worth and in the sixties would reach into previously untrod areas such as rural and urban poverty in the state. 
The decade of the fifties, hard times and all, required programs designed to cope with those difficult years and to provide social and economic adjustments to major change. The decade testified to the persistence, flexibility, and responsiveness of the Iowa State Cooperative Extension Service; it also revealed the increasing complexity of Iowa's agricultural sector. Altogether, the decade of the fifties brought major change both to Extension and to Iowa's farm families, changes that would call for even greater adjustments in the decades ahead. 
Copyright of Annals of Iowa is the property of State of Iowa, by \& through the State Historical Society of Iowa and its content may not be copied or emailed to multiple sites or posted to a listserv without the copyright holder's express written permission. However, users may print, download, or email articles for individual use. 